Fixed Point Theory, 22(2021), No. 1, 241-250

DOI: $10.24193 /$ fpt-ro.2021.1.17

http://www.math.ubbcluj.ro/ nodeacj/sfptcj.html

\title{
COMMON FIXED POINT THEOREMS IN PARTIAL IDEMPOTENT-VALUED METRIC SPACES
}

\author{
M. IRANMANESH*, S. RADENOVIĆ** AND F. SOLEIMANY*** \\ *Department of Mathematical Sciences, Shahrood University of Technology, \\ Shahrood, Iran \\ E-mail: m.iranmanesh2012@gmail.com
}

**Faculty of Mechanical Engineering, University of Belgrade, Serbia E-mail: radens@beotel.rs

*** Department of Mathematical Sciences, Shahrood University of Technology, Shahrood, Iran

E-mail:enfazh.bmaam@gmail.com

\begin{abstract}
In this article, we consider complete partial idempotent-valued metric spaces and prove some common fixed point theorems in the setting of cone metric spaces over idempotent space.

Key Words and Phrases: Partial metric space, common fixed points.

2020 Mathematics Subject Classification: 47H10, 26B25, 06A06.
\end{abstract}

Acknowledgment. The authors are very grateful to the anonymous referee for his or her comments and suggestions.

\section{REFERENCES}

[1] M. Abbas, G. Jungck, Common fixed points results for noncommuting mapping without continuity in cone metric space, J. Math. Anal. Appl., 341(2008), 416-420.

[2] I. Altun, A. Erduran, Fixed point theorems for monotone mappings on partial metric spaces, Fixed Point Theory Appl., 2011, art. ID 508730 (2011).

[3] I. Altun, F. Sola, H. Simsek, Generalized contractions on partial metric spaces, Topol. Appl., 157(18)(2010), 2778-2785

[4] J. Caballero, J. Harjani, K. Sadarangani, Contractive-like mapping principles in ordered metric spaces and applications to ordinary differential equations, Fixed Point Theory Appl., 2010, art. ID 916064 (2010).

[5] A.A. Eldred, P. Veeramani, Existence and convergence of best proximity points, J. Math. Anal. Appl., 323(2006), 1001-1006.

[6] L.G. Huang, X. Zhang, Cone metric spaces and fixed point theorems of contractive mappings, J. Math. Anal. Appl., 332(2007), no. 2, 1468-1476.

[7] D. Paesano, P. Vetro, Common fixed points in a partially ordered partial metric space, Int. J. Anal., 2013, art. ID 428561.

[8] S. Radenović, Common fixed points under contractive conditions in cone metric spaces, Comput. Math. Appl., 58(2009), 123-1278.

[9] S. Radenović, V. Rakoćević, Sh. Rezapour, Common fixed points for $(g, f)$ type maps in cone metric spaces, Appl. Math.Comput., 218(2011), 480-491. 
[10] J.C. Yeol, S. Reza, S.H. Wang, Common fixed point theorems on generalized distance in ordered cone metric spaces, Comput. Math. Appl., 61(2011), 1254-1260.

Received: April 4, 2018; Accepted: July 7, 2018. 
